\title{
Estudio experimental y modelo teórico del hormigón confinado lateralmente con polímeros reforzados con fibras (FRP)
}

\section{Concrete laterally confined with fibre-reinforced polymers (FRP): experimental study and theoretical model}

\author{
C. Aire(*), R. Gettu(**), J. R. Casas ${ }^{(* * *)}$, S. Marques ${ }^{(* * * *)}$, D. Marques(****)
}

Recepción/Received: 7-I-08

Aceptación/Accepted: 25-XI-08

Publicado online/Online publishing: 25-II-10

\section{RESUMEN}

Este trabajo presenta los resultados de un estudio experimental y analítico del comportamiento de elementos de hormigón confinados con polímeros reforzados con fibras (FRP) de vidrio y carbono. El programa experimental consistió en ensayar cilindros de hormigón de 150 × 300 mm (confinados y sin confinar) bajo compresión axial en dos niveles de resistencia: normal (30 MPa) y alta resistencia (70 MPa). En ambos casos, se evaluó el comportamiento tensión-deformación. Los resultados muestran que la resistencia y ductilidad se incrementan con el confinamiento con FRP.

A partir de los resultados experimentales, se desarrolló un modelo analítico para predecir el comportamiento tensión-deformación del hormigón confinado con FRP. La comparación de los resultados experimentales y analíticos muestra que el modelo es aplicable a los hormigones estudiados, proporcionando predicciones satisfactorias del comportamiento tensión-deformación y de la resistencia a compresión última.

Palabras clave: resistencia a compresión, confinamiento, comportamiento tensión-deformación, modelo de confinamiento.

\section{SUMMARY}

This paper presents the findings of an experimental and analytical study of concrete cylinder behaviour when wrapped in fibreglass or carbon fibre-reinforced polymers (FRP). Compression testing was conducted on normal (30 MPa) and high (70 MPa) strength confined and unconfined concrete cylinders measuring $150 \times 300$ $\mathrm{mm}$. The stress-strain relationship was evaluated in both cases. The findings showed that strength and ductility rose with FRP confinement.

The experimental findings were used to develop an analytical model for predicting the stress-strain behaviour of FRP-confined concrete. A comparison of the experimental and analytical results revealed that the model can satisfactorily predict the stress-strain behaviour and ultimate compressive strength of the concretes studied.

Keywords: compressive strength, confinement, stressstrain relationship, confinement model.

\footnotetext{
(*) Universidad Nacional Autónoma de México (México D.F., México).

(**) Indian Institute of Technology (Madrás, India).

(***) Universidad Politécnica de Cataluña (Barcelona, España).

(****) Univ. Federal de Alagoas (Brasil).
} 


\section{INTRODUCCIÓN}

En los años pasados se ha incrementado el uso de los materiales compuestos, como el polímero reforzado con fibras (FRP, por sus siglas en inglés Fiber Reinforced Polymers), para reforzar o reparar estructuras de hormigón. Actualmente, existen varios tipos de FRP que son considerados en la industria de la construcción y reparación, como los FRP de vidrio, carbono y aramida. Estos compuestos se caracterizan por su elevada resistencia, peso ligero, fácil manipulación, transporte e instalación. Se han realizado diversos estudios sobre cilindros de hormigón confinados con FRP que demuestran que el uso de estos materiales incrementa la resistencia, deformación última y ductilidad con respecto a los cilindros de hormigón convencional (1-5). Sin embargo, la mayoría de los estudios se han realizado en cilindros pequeños (50 $\mathrm{x}$ $100,75 \times 150$ y $100 \times 200 \mathrm{~mm}$ ) fabricados con hormigones de resistencias entre 15 y $50 \mathrm{MPa}$ (5-9). Además, se han propuesto diversos modelos analíticos para predecir el comportamiento tensión-deformación (1-4, 8-11), muchos de los cuales han sido derivados de modelos existentes desarrollados para hormigón armado con acero de refuerzo y predicen, en algunos casos, la resistencia y deformación última, y en otros, el comportamiento tensión-deformación. Debido al incremento del uso de los FRP en la industria de la construcción, varios comités de organizaciones profesionales han desarrollado y publicado recomendaciones de diseño, técnicas de construcción y uso, especificaciones, métodos de ensayo y sus aplicaciones (12-15). A pesar de las aplicaciones exitosas del uso de los FRP en prototipos de laboratorio y aplicaciones en campo, es todavía necesaria una mayor investigación para comprender el mecanismo de interacción entre los FRP y el hormigón, porque la información es limitada en cuanto a niveles de resistencia y tamaño de probetas.

\section{RELEVANCIA DE LA INVESTIGACIÓN}

Este trabajo presenta los resultados de un estudio sobre cilindros de hormigón, de resistencia normal y alta, confinados con materiales compuestos (FRP) ensayados a compresión axial. Se analiza la influencia del número de capas de confinamiento sobre la resistencia y deformación última de los hormigones. También se propone un modelo analítico para predecir el comportamiento tensión-deformación del hormigón confinado y sin confinar de cilindros de hormigón cargados axialmente. El modelo se basa en la idea de que la rigidez axial del hormigón confinado y sin confinar está relacionada con la deformación lateral.

\section{INTRODUCTION}

The use of composite materials such as fibre-reinforced polymers (FRP) to reinforce or repair concrete structures has been on the rise in recent years. Today the construction and retrofitting industries have a number of types of FRP from which to choose, such as fibreglass, carbon fibre and aramid polymers. In addition to being strong and lightweight, these compounds are easy to handle, ship and install. Studies on FRP-confined concrete cylinders have shown that the use of these materials increases the strength, ultimate strain and ductility of conventional concrete (1-5). Nonetheless, most of these studies have been conducted on small concrete cylinders (50 x 100, $75 \times 150$ y $100 \times 200$ mm) in a strength range of 15 to $50 \mathrm{MPa}$ (5-9). Analytical models have also been put forward to predict stressstrain behaviour (1-4, 8-11), many of which were derived from existing models developed for steelreinforced concrete. In some cases, they predict strength and ultimate strain and in others stress-strain behaviour. With the increasing use of FRP in construction, a number of professional organizations have created committees that have developed and published design recommendations, construction techniques and use, specifications, testing methods and applications (12-15). Despite the successful use of FRP in laboratory prototypes and field applications, however, in light of the fairly limited information available on strength levels and specimen sizes, further research is needed to gain insight into the mechanisms governing concrete-FRP interaction.

\section{RELEVANCE OF THE RESEARCH}

This paper presents the findings of compression testing on normal and high strength concrete cylinders confined with composite materials (FRP). The effect of the number of confinement layers on concrete strength and ultimate strain is analyzed. An analytical model is also proposed to predict the stress-strain relationship of confined and unconfined concrete in axially loaded concrete cylinders. The model is based on the assumption that the axial stiffness of confined and unconfined concrete is related to lateral strain. 


\section{PROGRAMA EXPERIMENTAL}

\subsection{Detalles del estudio}

El estudio consistió en ensayar a compresión axial cilindros de hormigón sin confinar y confinados con fibras de carbono y vidrio (FRP). Se usó cemento CEM I-52.5R, humo de sílice densificada, árido fino y grueso $(5-12 \mathrm{~mm})$ de origen calizo y un aditivo superplastificante de base naftaleno. La tabla 1 muestra las proporciones de mezcla. Se fabricaron dos tipos de hormigón, con resistencias nominales de $30 \mathrm{MPa}(\mathrm{HF} 30)$ y $70 \mathrm{MPa}$ (HF70) y se moldearon cilindros de $150 \times 300 \mathrm{~mm}$. Para el confinamiento se usó fibras de carbono y vidrio; la de carbono es una fibra unidireccional de 0,117 $\mathrm{mm}$ de espesor, 3,9 GPa de resistencia a tracción, $240 \mathrm{GPa}$ de módulo elástico, $1,55 \%$ de elongación máxima, y la de vidrio es una fibra bidireccional (GAR 90/10) de 0,149 mm de espesor, $3 \mathrm{GPa}$ de resistencia tracción, $65 \mathrm{GPa}$ de módulo elástico y $4,3 \%$ de elongación máxima. Se consideró un amplio rango de capas de confinamiento, entre 0 y 6 capas para el hormigón HF30 y entre 0 y 12 para el hormigón HF70. En cada caso se ensayaron 3 cilindros.

\section{EXPERIMENTAL}

\subsection{Details}

The study consisted in compression testing unconfined and fibreglass and carbon-fibre (FRP)-confined concrete cylinders. The constituents used to prepare the concrete were cement CEM I-52.5R, densified silica fume, fine and coarse limestone aggregate (5-12 $\mathrm{mm}$ ) and a naphthalene-based superplasticizer. The mix proportions are given in Table 1. Two types of concrete were moulded into 150 x 300- $\mathrm{mm}$ cylinders, distinguished by their strength: 30 (HF30) and 70 (HF70) MPa. Fibreglass and carbon fibres were used for the confinement. Carbon fibres are one-directional and $0.117 \mathrm{~mm}$ thick and have a tensile strength of $3.9 \mathrm{GPa}$, a modulus of elasticity of $240 \mathrm{GPa}$ and a maximum elongation of $1.55 \%$. Fibreglass, in turn, is twodirectional (GAR 90/10) and $0.149 \mathrm{~mm}$ thick, and has a tensile strength of 3 GPA, a modulus of elasticity of 65 GPa and a maximum elongation of $4.3 \%$. A wide range of confinement layers was tested, from 0 to 6 for concrete HF30 and 0 to 12 for HF70. Three cylinders of each type were tested.

Tabla 1 / Table 1

Proporciones de mezcla por $\mathrm{m}^{3}$ Mix proportions per $\mathrm{m}^{3}$.

\begin{tabular}{|c|c|c|}
\hline Componente / Component & Hormigón / Concrete (HF30) & Hormigón / Concrete (HF70) \\
\hline Cemento / Cement, $\mathrm{kg}$ & 349 & 480 \\
\hline Arena / Sand, $\mathrm{kg}$ & 873 & 840 \\
\hline Grava / Gravel, $\mathrm{kg}$ & 978 & 921 \\
\hline Humo de sílice / Silica fume, $\mathrm{kg}$ & - & 48 \\
\hline Agua total / Total water, kg & 226 & 165 \\
\hline Superplastificante, lit. / Superplasticizer, / & 2.1 & 23 \\
\hline Relación agua/cemento (a/c) / Water/cement (w/c) ratio & 0.59 & 0.34 \\
\hline
\end{tabular}

\subsection{Preparación de los cilindros confinados con FRP}

En la Figura 1 se puede ver el procedimiento típico utilizado para el confinamiento de las probetas. Para asegurar la adherencia de la fibra, en primer lugar se aplica un imprimante sobre el cilindro. A continuación se coloca la fibra, previamente impregnada con el adhesivo epoxi. Para asegurar una correcta colocación de la fibra sobre la probeta, se utiliza un rodillo de ranuras con el que se presiona la fibra. En caso de que haya que aplicar varias capas, se repite la operación anterior, asegurando que entre capa y capa exista un solape de $150 \mathrm{~mm}$.

\subsection{Preparation of FRP-confined cylinders}

Figure 1 illustrates the standard procedure used to confine the specimens. Each cylinder was first coated with a primer to ensure the fibre would bond to the concrete. The fibre was covered with epoxy glue and then wrapped around the specimen. A grooved roller was used to press the fibre against the concrete for a good bond. When more than one layer was applied, the above operation was repeated, with a $150-\mathrm{mm}$ overlap between each two adjacent layers. 


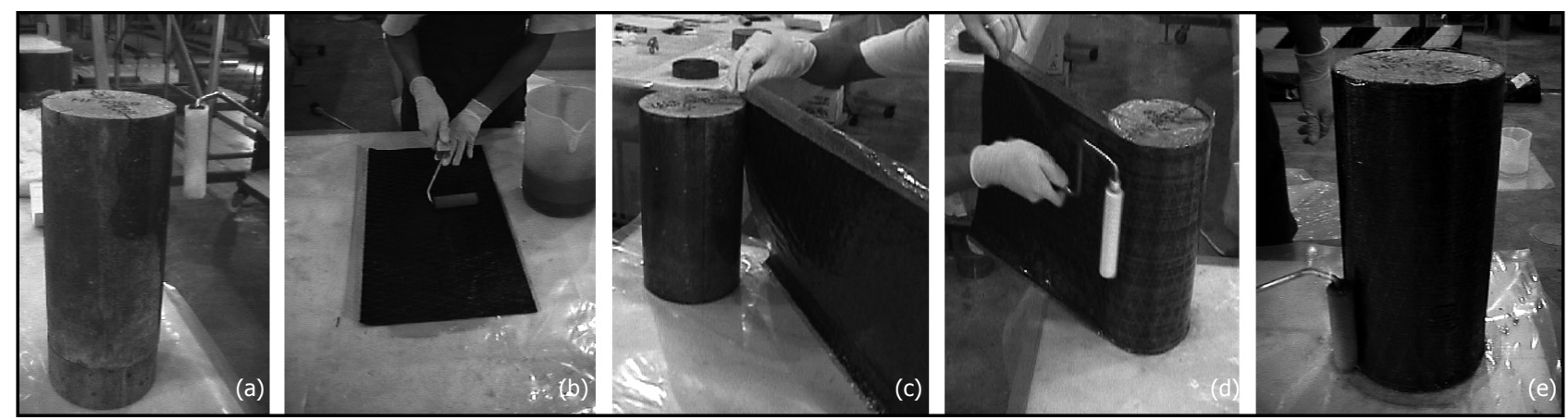

Figura 1. Confinamiento típico: (a) Imprimación, (b) Aplicación de sistema epoxy sobre la capa de FRP, (c) Colocación de la primera capa de FRP, (d) Aplicación de rodillo de ranura, (e) Última capa de epoxy.

Figure 1. Standard confinement: (a) Priming; (b) Applying epoxy glue to the FRP; (c) Wrapping the first layer of FRP around the specimen; (d) Pressing with a grooved roller; (e) Applying last layer of epoxy glue.

\subsection{Procedimiento de ensayo}

Todos los cilindros fueron ensayados a compresión axial hasta la rotura, usando una prensa servohidráulica con capacidad de 4,5 MN. El ensayo de cilindros sin confinar se hizo por control de desplazamiento circunferencial, para esto se colocó un extensómetro circunferencial (MTS 632.1F.20) de $12,5 \mathrm{~mm}$ de rango, mientras que el ensayo de cilindros confinados se hizo por control de desplazamiento del pistón de la prensa. En ambos casos, la instrumentación fue con bandas extensométricas pegadas en el cilindro (PL-60-1-1L en los cilindros sin confinar y PFL-10-11 en los cilindros confinados) y con transductores de desplazamiento tipo LVDT de $\pm 7,5 \mathrm{~mm}$ de rango. Las pruebas se hicieron a una velocidad constante de desplazamiento de 0,005 $\mathrm{mm} / \mathrm{seg}$. En el caso del hormigón confinado, la carga se aplicó únicamente sobre la superficie de hormigón, para lo cual se colocaron, en la parte inferior y superior del cilindro, placas circulares de acero de $150 \mathrm{~mm}$ de diámetro y $45 \mathrm{~mm}$ de espesor. Las bandas extensométricas axial y transversal fueron pegadas a la mitad de la altura de cada cilindro. Se utilizó un sistema computerizado para registrar los datos de carga y deformación durante la prueba.

\section{RESULTADOS}

\subsection{Modo de rotura}

Los cilindros sin confinar presentaron una rotura típica, con grietas paralelas a la dirección de la carga y en los cilindros confinados estuvo gobernada por la rotura de la fibra en dirección perpendicular a la fibra, siendo más explosiva en el caso de los cilindros confinados con fibra de carbono. En todos los casos la rotura de la fibra se presentó lejos de la zona de solape.

\subsection{Comportamiento tensión-deformación}

La Figura 2 muestra el comportamiento tensión-deformación de los hormigones estudiados. Es evidente el

\subsection{Test procedure}

All cylinders were compression tested to failure in a 4.5MN servo-hydraulic test frame. The unconfined cylinders were tested by monitoring circumferential displacement with a 12.5- $\mathrm{mm}$ range circumferential strain gauge (MTS 632.1F.20). Displacement in the confined cylinders, in turn, was monitored with the test frame piston. In both cases, the instrumentation consisted in strain gauges (PL-60-1-1L in the unconfined and PFL-10-11 in the confined cylinders) glued to the cylinder and LVDT type displacement transducers with a range of $\pm 7.5 \mathrm{~mm}$. The testing speed was a constant $0.005 \mathrm{~mm} / \mathrm{sec}$. In the confined concrete, the load was applied to the concrete surface only, placing circular steel plates $150 \mathrm{~mm}$ in diameter and $45 \mathrm{~mm}$ thick on the top and bottom of the cylinder. The axial and transverse strain gauges were glued to each cylinder at mid-height. Load and strain data recording was computerized.

\section{RESULTS}

\subsection{Failure mode}

The unconfined cylinders exhibited typical failure, with cracks parallel to the direction of the load. Failure in the confined cylinders was governed by and perpendicular to the fibre, and took place more explosively in the cylinders wrapped in carbon fibre. In all cases fibre failure occurred at a substantial distance from the overlap.

\subsection{Stress-strain relationship}

Figure 2 shows the stress-strain curves for the concretes studied. An obvious post-peak decline was observed in 
post-pico descendente en la respuesta tensión-deformación del hormigón sin confinar, sin embargo, en el hormigón confinado se presenta un tramo ascendente hasta alcanzar un valor máximo. En todos los casos, el confinamiento con FRP de carbono y vidrio incrementa la tensión y deformación máximas. Para 3 o más capas de confinamiento las curvas presentan un comportamiento de endurecimiento que se evidencia por el cambio de la pendiente de la curva que se presenta alrededor de la carga máxima del hormigón sin confinar. Aunque la pendiente de las curvas tensión-deformación transversal se incrementa con el número de capas, las máximas deformaciones transversales no se incrementan significativamente, especialmente para 3 o más capas, lo que significa que la rotura es gobernada por la rotura del FRP en cierto valor de deformación máxima. the curves for the unconfined concrete, while in the confined specimens the slopes continued to climb to a maximum value. Confinement with carbon fibre and fibreglass FRP raised the maximum stress and strain in all cases. Hardening was observed in specimens with three or more layers, denoted by the change in the slope of the curve at around the maximum value attained by the unconfined concrete. Although the slope on the stress-transverse strain curves grew with the number of layers, the peak transverse strain did not rise significantly, particularly for three or more layers. This finding infers that cylinder failure was governed by FRP failure at a certain maximum strain value.

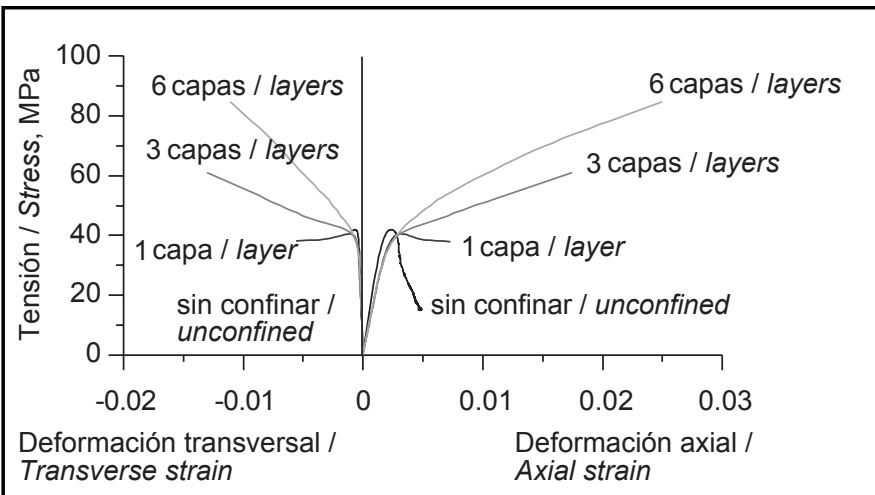

a) Cilindros HF30 con fibra de vidrio /

a) HF30 cylinders with fibreglass

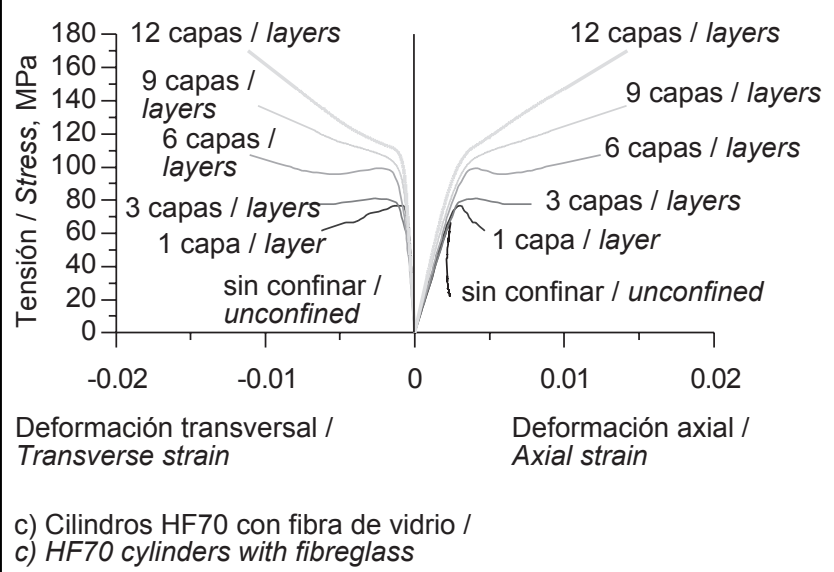

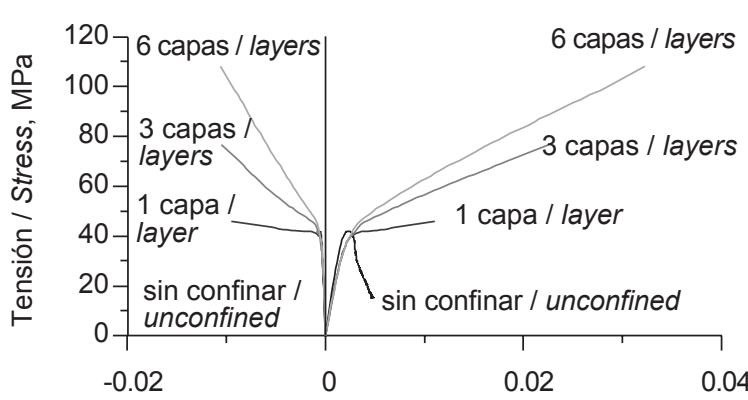

Deformación transversal / Transverse strain

Deformación axial / Axial strain

b) Cilindros HF30 con fibra de carbono /

b) HF30 cylinders with carbon fibre

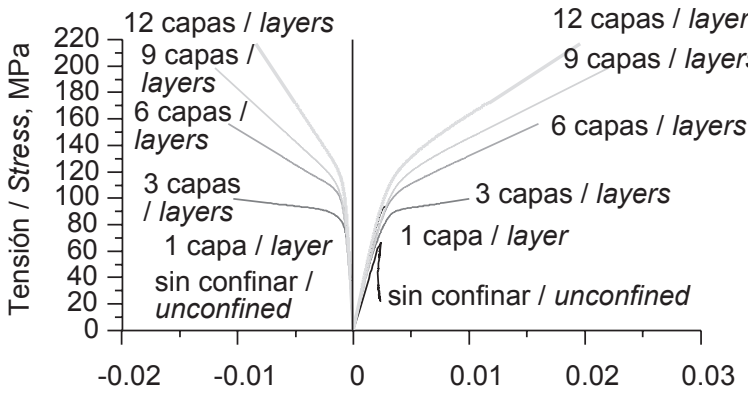

Deformación transversal / Transverse strain

Deformación axial /

d) Cilindros HF70 con fibra de carbono /

d) HF70 cylinders with carbon fibre

Figura 2. Curvas tensión-deformación típicas del hormigón sin confinar y confinado con FRP. Figure 2. Typical stress-strain curves for unconfined and FRP-confined concrete

\subsection{Tensión máxima}

La Tabla 2 presenta los resultados de los ensayos (promedio de 3 ensayos) donde $f_{c \text { max }}^{\prime}$, es la tensión máxima, $\varepsilon_{\text {max }}$ su correspondiente deformación axial y $\varepsilon_{\text {tmax }}$ la deformación transversal de los hormigones confinados,

\subsection{Maximum stress}

Table 2 gives the results of the tests (mean of three trials), where $f_{c \max }^{\prime}$ is the peak stress, $\varepsilon_{\max }$ the respective axial strain and $\varepsilon_{\text {tmax }}$ the transverse strain on the confined concrete, while $f_{c o}^{\prime}, \varepsilon_{c o}$, and $\varepsilon_{t}$ represent 
mientras que $f_{c o}^{\prime}, \varepsilon_{c o}$, y $\varepsilon_{t}$, es la tensión, y deformación axial y transversal máxima de los hormigones sin confinar. V y C indican el tipo de fibra FRP (vidrio y carbono) y el número a su derecha indica el número de capas de FRP. De la Tabla se observa que el incremento en la resistencia es mayor para el confinamiento con fibra de carbono; esto se debe a la mayor rigidez de esta fibra. Además, el incremento en la resistencia es menor en el hormigón de mayor resistencia (HF70), debido a la menor capacidad de deformación axial de estos hormigones, que genera menor deformación transversal, por lo tanto ejerce menor presión de confinamiento al núcleo de hormigón. Además, el índice de ductilidad, medido como $\varepsilon_{\mathrm{max}} / \varepsilon_{\mathrm{co}}$, es mayor para el hormigón confinado con FRP de carbono, lo que se debe al mayor módulo de elasticidad y resistencia de estas fibras. Sin embargo, debe comentarse que los valores máximos que se muestran en la Tabla 2 corresponden a los últimos valores registrados en el ensayo cercano a la carga máxima. En este estado, cerca de la rotura, se producen grandes deformaciones transversales y es posible que las bandas extensométricas puedan despegarse de la superficie del hormigón. En estas condiciones las deformaciones últimas registradas no serían valores reales correspondientes a la rotura, de modo que los valores últimos real y medido podrían diferenciarse uno del otro. Si la rotura de la probeta provoca la fractura de las fibras, la deformación transversal última en las probetas confinadas con fibra de carbono debería ser menor que la que se produce en las confinadas con fibra de vidrio. the maximum stress and axial and transverse strain on the unconfined concretes. $V$ and $C$ specify the type of FRP fibre (fibreglass or carbon) and the number at the right, the number of FRP layers. The table shows that the increase in strength was higher when the concrete was confined with carbon fibre, which is stiffer than fibreglass. Moreover, strength rose less in the higher strength concrete (HF70) due to the lower axial deformability of these materials. This translated into less transverse strain and less confinement pressure on the concrete core. In addition, the higher modulus of elasticity and strength of carbon fibre FRP-confined concrete led to a higher ductility factor, defined to be $\varepsilon_{\max } / \varepsilon_{c o}$, in the concrete confined with this material. The maximum values given in Table 2, however, are the last values recorded before failure. As a result of the sizeable transverse strain arising immediately prior to failure, the strain gauges may become detached from the concrete surface. Under such circumstances the last strain values recorded would not reflect the actual failure values, i.e., the real and measured ultimate values may differ. If the fibres break as a result of specimen failure, the ultimate transverse strain on the specimens confined with carbon fibre should be smaller than on the cylinders confined with fibreglass.

Tabla 2 / Table 2

Resumen de resultados de los ensayos. Summary of test results.

\begin{tabular}{|c|c|c|c|c|c|c|c|}
\hline \multirow{2}{*}{ Hormigón / Concrete } & $\mathbf{e}$ & $\mathbf{f}_{c \operatorname{cmax}}^{\prime}$ & $\mathbf{f}_{\text {cmax }}^{\prime} / \mathbf{f}_{\text {co }}^{\prime}$ & $\varepsilon_{\max }$ & $\varepsilon_{\max } / \varepsilon_{c o}$ & $\varepsilon t_{\max }$ & $\varepsilon \mathbf{t}_{\max } / \varepsilon_{\mathrm{t}}$ \\
\hline & $\mathbf{m m}$ & (MPa) & - & $\times 10^{-3}$ & & $\times 10^{-3}$ & \\
\hline HF30 & 0 & $f_{C O}^{\prime}=42$ & - & $\varepsilon_{\mathrm{co}}=2.4$ & - & $\varepsilon_{\mathrm{t}}=0.6$ & - \\
\hline HF30-V1 & 0.149 & 41 & 1.0 & 2.5 & 1.1 & 0.9 & 1.4 \\
\hline HF30-V3 & 0.447 & 61 & 1.5 & 17.1 & 7.2 & 12.8 & 20.2 \\
\hline HF30-V6 & 0.894 & 85 & 2.0 & 20.2 & 8.4 & 11.3 & 17.8 \\
\hline HF30-C1 & 0.117 & 46 & 1.1 & 9.2 & 3.8 & 8.8 & 13.9 \\
\hline HF30-C3 & 0.351 & 77 & 1.8 & 21.2 & 8.8 & 9.3 & 14.6 \\
\hline HF30-C6 & 0.702 & 108 & 2.6 & 31.6 & 13.2 & 10.5 & 16.5 \\
\hline HF70 & 0 & $f_{C O}^{\prime}=69$ & - & $\varepsilon_{\mathrm{CO}}=2.4$ & - & $\varepsilon_{\mathrm{t}}=0.4$ & - \\
\hline HF70-V1 & 0.149 & $79^{*}$ & 1.1 & 2.4 & 1.0 & 1.1 & 2.5 \\
\hline HF70-V3 & 0.447 & $83^{*}$ & 1.2 & 2.6 & 1.1 & 2.0 & 4.7 \\
\hline HF70-V6 & 0.894 & $107^{*}$ & 1.5 & 6.2 & 2.6 & 8.9 & 20.5 \\
\hline HF70-V9 & 1.341 & $140^{*}$ & 2.0 & 14.1 & 5.9 & 9.7 & 22.3 \\
\hline HF70-V12 & 1.788 & 170 & 2.5 & 14.7 & 6.1 & 11.0 & 25.3 \\
\hline HF70-C1 & 0.117 & $94^{*}$ & 1.3 & 2.7 & 1.1 & 0.9 & 2.0 \\
\hline HF70-C3 & 0.351 & $98^{*}$ & 1.4 & 7.8 & 3.2 & 8.2 & 18.9 \\
\hline HF70-C6 & 0.702 & 156 & 2.3 & 16.3 & 6.8 & 10.3 & 23.7 \\
\hline HF70-C9 & 1.053 & $199^{*}$ & 2.9 & 22.8 & 9.5 & 11.4 & 26.1 \\
\hline HF70-C12 & 1.404 & 217 & 3.1 & 23.9 & 9.9 & 8.5 & 19.5 \\
\hline
\end{tabular}

* Promedio de 2 valores / Mean of two values. 


\subsection{Modelo de confinamiento}

Se ha desarrollado un modelo analítico para predecir el comportamiento del hormigón confinado (16). La Figura 3 muestra el diagrama de flujo del modelo propuesto que es aplicable para predecir el comportamiento del hormigón confinado con FRP, cuando la carga se aplica sobre la superficie de hormigón y se basa en los modelos de Razvi y Saatcioglu (11) y Mander et al. (17) y permite obtener la respuesta tensión-deformación del hormigón confinado para cada valor de presión de confinamiento lateral. El modelo se basa en la idea de que la rigidez axial del hormigón confinado y sin confinar está relacionada directamente con la deformación lateral. Como la presión lateral varía con la deformación axial, la respuesta corresponde a una infinidad de curvas tensión-deformación durante el proceso de deformación. Considerando esto, el modelo sigue un proceso iterativo, basado en el modelo de Spoelstra y Monti (10) para incorporar la relación tensión-deformación cuantitativa del hormigón confinado. De acuerdo al diagrama de flujo que se muestra en la Figura 3, el modelo se aplica de la siguiente manera:

1. Se introduce un valor inicial para la deformación axial $\varepsilon_{c}$.

2. Se asume un valor para la deformación lateral (por ejemplo, $\left.\varepsilon_{/}=\mu \varepsilon_{C}\right)$.

3. Calcula la presión lateral $f_{l}$ correspondiente a la deformación lateral $\varepsilon$.

4. Se obtiene la tensión de compresión del hormigón $f_{c c}^{\prime}$ asociada a $f_{C O}^{\prime}$ y $f_{\text {. }}$. El modelo incorpora varios criterios de rotura, que el usuario puede elegir: Criterio de Mander et al. (17), Razvi y Saatcioglu (11) y Cusson y Paultre (18), entre otros.

5. Con $\varepsilon_{C}$ y $f_{C O}^{\prime}$ se determina $f_{C \text {. }}$

6. Con $\varepsilon_{C}$ y $f_{C C}^{\prime}$ se calcula la deformación de área $\varepsilon_{A}$.

7. Haciendo $\varepsilon_{l}=\varepsilon_{A} / 2$, se obtiene un nuevo valor de $f_{\text {. }}$.

8. Si este nuevo valor de $f_{l}$ es prácticamente igual al anterior (tolerancia asumida por el usuario), se asume que se ha encontrado un punto $\left(\varepsilon_{C}, f_{C}\right)$ de la curva tensión-deformación. Entonces, se incrementa el valor de la deformación $\varepsilon_{C}$ y se repite la operación hasta encontrar un nuevo valor. En caso de que el

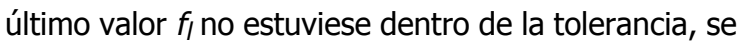
asume este valor de $f_{l}$ como nuevo valor de la presión lateral y se calcula nuevamente el valor $f_{c c}^{\prime}$ repitiéndose la secuencia de operaciones.

9. El programa finaliza cuando el valor $\varepsilon_{C}$ alcanza el valor $\varepsilon_{c m a x}$ predefinido.

A continuación se enumeran algunas consideraciones y expresiones útiles para el desarrollo del modelo. Para mayores detalles referirse a Marques y Marques (16).

El modelo es aplicable para predecir el comportamiento del hormigón confinado con tubo de acero y FRP, cuando

\subsection{Confinement model}

An analytical model was developed to predict the behaviour of confined concrete (16). The flow chart for the proposed model is given in Figure 3. This model, which is based on the Razvi and Saatcioglu (11) and Mander et al. (17) models, can predict the behaviour of FRP-confined concrete subjected to loads applied on the surface. It also gives the stress-strain response of confined concrete for each lateral confinement pressure value. The model is based on the assumption that the axial stiffness of confined and unconfined concrete is related to lateral strain. Since lateral pressure varies with axial strain, the response elicited during the process corresponds to an infinite number of stress-strain curves. The model is therefore iterative and borrows from the Spoelstra and Monti (10) model to include the quantitative stress-strain relationship of confined concrete. Further to the flow chart in Figure 3, the model is implemented as follows:

1. An initial value is entered for axial strain, $\varepsilon_{c}$.

2. A value is assumed for lateral strain (such as $\varepsilon_{l}=$ $\left.\mu \varepsilon_{c}\right)$.

3. The lateral pressure, $f_{l}$, corresponding to the lateral strain, $\varepsilon_{l}$, is calculated.

4. The compression stress on the concrete, $f_{c c}^{\prime}$, associated with $f_{c o}^{\prime}$ and $f_{l}$ is found. Users are given a choice of failure criteria that may be run on the model: Mander et al. (17), Razvi and Saatcioglu (11) and Cusson and Paultre (18), among others.

5. $f_{C}$ is determined from $\varepsilon_{C}$ and $f_{c o}^{\prime}$.

6. Area strain, $\varepsilon_{A}$, is found with $\varepsilon_{C}$ and $f_{C}$.

7. Making $\varepsilon_{l}=\varepsilon_{A} / 2$, a new value of $f_{l}$ is found.

8. If this new $f_{l}$ is practically the same as the preceding value (tolerance defined by the user), a point $\left(\varepsilon_{c}, f_{c}\right)$ on the stress-strain curve is assumed to have been identified. The strain value, $\varepsilon_{c}$ is then increased and the operation is repeated until a new value is found. When an $f_{\text {l }}$ value falls outside the established tolerance, this value is assumed to constitute a new lateral pressure and a new $f_{c C}^{\prime}$ value is calculated as described above.

9. The program ends when $\varepsilon_{c}$ reaches the pre-defined $\varepsilon_{\text {cmax }}$ value.

A few considerations and useful remarks on model development are discussed below. See Marques and Marques (16) for further details.

The model, which can predict the behaviour of steel tube- and FRP-confined concrete for loads applied to the 
la carga se aplica sobre la superficie del hormigón y propone una relación constitutiva axial que adopta la deformación del área, denominada $\varepsilon_{A}$, como parámetro de control de la degradación de la rigidez. En consecuencia, la degradación del hormigón se relaciona con su deformación de área mediante: $\left(\varepsilon_{A}=2 \varepsilon_{l}\right)$ donde $\varepsilon_{l}$ es la deformación lateral. Este parámetro es usado como un indicador del estado de la degradación interna del hormigón cuando está sometido a una deformación axial creciente. Esta idea es la base del modelo constitutivo presentado por Pantazopoulou y Mills (19). El modelo de Marques y Marques (16) es un modelo constitutivo simple para hormigón sin confinar y confinado sometido a compresión axial y propone la siguiente relación [1]: concrete surface, proposes a constitutive axial relationship in which area strain, denominated $\varepsilon_{A}$, is the parameter adopted to monitor the decline in stiffness. Consequently, concrete deterioration is related to its area strain as $\left(\varepsilon_{A}=2 \varepsilon_{l}\right)$, where $\varepsilon_{l}$ is the lateral strain. This parameter is used as an indicator of the internal deterioration of concrete exposed to increasing axial strain, the underlying idea in the constitutive model proposed by Pantazopoulou and Mills (19). The Marques and Marques (16) model, a simple constitutive model for unconfined and confined concrete subjected to axial compression, proposes the following relationship [1]:

$$
f_{C}=\frac{E_{c}}{1+A\left(\varepsilon_{A}\right)^{\beta}} \varepsilon_{C}
$$

donde $E_{C}$ es el módulo tangente inicial del hormigón, $A$ y $\beta$ son constantes del material y $f_{C}$ es la tensión axial correspondiente a la deformación axial $\varepsilon_{c}$. En general, $\varepsilon_{A}$ es función de la deformación axial $\varepsilon_{C} y$ de la presión lateral de confinamiento $f_{\text {l }}$.

Las constantes del material del modelo de Marques y Marques (16), $A$ y $\beta$, son independientes de la presión de confinamiento y pueden ser calculados en función de las características mecánicas del hormigón sin confinar. Las expresiones son $[2,3]$ : where $E_{C}$ is the tangent model for the concrete, $A$ and $\beta$ are material constants and $f_{C}$ is the axial stress corresponding to axial strain $\varepsilon_{c}$. As a general rule, $\varepsilon_{A}$ is a function of axial stress, $\varepsilon_{c,}$ and the lateral confinement pressure, $f_{\text {. }}$.

The material constants in the Marques and Marques model (16), $A$ and $\beta$, are independent of the confinement pressure and can be calculated from the mechanical properties of the unconfined concrete. The respective expressions are $[2,3]$ :

$$
\begin{gathered}
A=\frac{E_{c} \varepsilon_{c o}-f_{c o}^{\prime}}{f_{c o}^{\prime}}\left(\varepsilon_{c o}\right)^{-\beta} \\
\beta=\frac{1}{4-6_{\mu}}\left(1+\frac{f_{c o}^{\prime}}{E_{c} \varepsilon_{c o}-f_{c o}^{\prime}}\right)
\end{gathered}
$$

Para el desarrollo del proceso iterativo para hormigón confinado se utiliza otro modelo constitutivo que describe el comportamiento tensión-deformación para una determinada presión lateral. Para esto Marques y Marques (16) utilizan una expresión propuesta por Mander et al. (17) [4]:
The iterative process for confined concrete draws from another constitutive model that describes the stressstrain behaviour for a given lateral pressure. Marques and Marques (16) apply an expression proposed by Mander et al. (17) for this purpose [4]:

$$
f_{c}=\frac{f_{c c}^{\prime}\left(\frac{\varepsilon_{c}}{\varepsilon_{c c}}\right) r}{r-1+\left(\frac{\varepsilon_{c}}{\varepsilon_{c c}}\right)^{r}}
$$

donde $f_{c c}^{\prime}$ es la resistencia a compresión del hormigón confinado y $\varepsilon_{c c}$ su deformación axial correspondiente. Además [4-8]: where $f_{c c}^{\prime}$ is the compressive strength of the confined concrete and $\varepsilon_{c c}$ its respective axial strain. Moreover [4-8]: 


$$
\begin{gathered}
r=\frac{E_{c}}{E_{c}-E_{s c c}} \\
E_{s c c}=\frac{f_{c c}^{\prime}}{\varepsilon_{c c}} \\
\varepsilon_{c c}=\varepsilon_{c o}\left[1+5\left(\frac{f_{c c}^{\prime}}{f_{c o}^{\prime}}-1\right)\right] \\
E_{c}=3320 \sqrt{f_{c o}^{\prime}}+6900
\end{gathered}
$$

donde $E_{C}$ es el módulo de elasticidad del hormigón confinado, en MPa.

Para el caso de cilindros de hormigón confinado por espirales o estribos circulares, Mander et al. (17) propone la siguiente expresión [9]: where $E_{C}$ is the modulus of elasticity of the confined concrete in $\mathrm{MPa}$.

For concrete cylinders confined by spirals or circular stirrups, Mander et al. (17) propose the following expression [9]:

$$
f_{c C}^{\prime}=f_{c o}^{\prime}\left(\sqrt{1+7.94 \frac{f_{I}}{f_{c o}^{\prime}}}-2 \frac{f_{l}}{f_{c o}^{\prime}}-1.254\right)
$$

Razvi y Saatcioglu (11) proponen que la resistencia a compresión y deformación axial del hormigón confinado vienen dados por [10-12]:
Razvi and Saatcioglu (11) maintain that confined concrete compressive strength and axial strain can be given by [10-12]:

$$
\begin{gathered}
f_{c c}^{\prime}=f_{c o}^{\prime}+k_{1} f_{I} \\
\varepsilon_{c c}=\varepsilon_{c o}\left(1+5 k_{3} K\right)
\end{gathered}
$$

donde

where

$$
\begin{gathered}
k_{3}=\frac{40}{f_{c o}^{\prime}} \leq 1 \quad \text { y } \quad K=\frac{k_{1} f_{l}}{f_{c o}^{\prime}} \\
k_{1}=6.7\left(f_{l}\right)^{-0.17}
\end{gathered}
$$

En el caso de hormigón de sección circular confinado por encamisado lateral, la presión de confinamiento puede obtenerse en función de la deformación lateral, que coincide con la deformación circunferencial del encamisado, mediante la expresión [13]:

$$
f_{l}=\frac{2 t}{d} E_{s} \varepsilon_{l}
$$

donde $E_{S}$ es el módulo de elasticidad circunferencial del encamisado.
For circular section concrete confined by a lateral wrapping, the confinement pressure can be obtained from the lateral strain, which concurs with the circumferential strain on the wrapping, as follows [13]: 


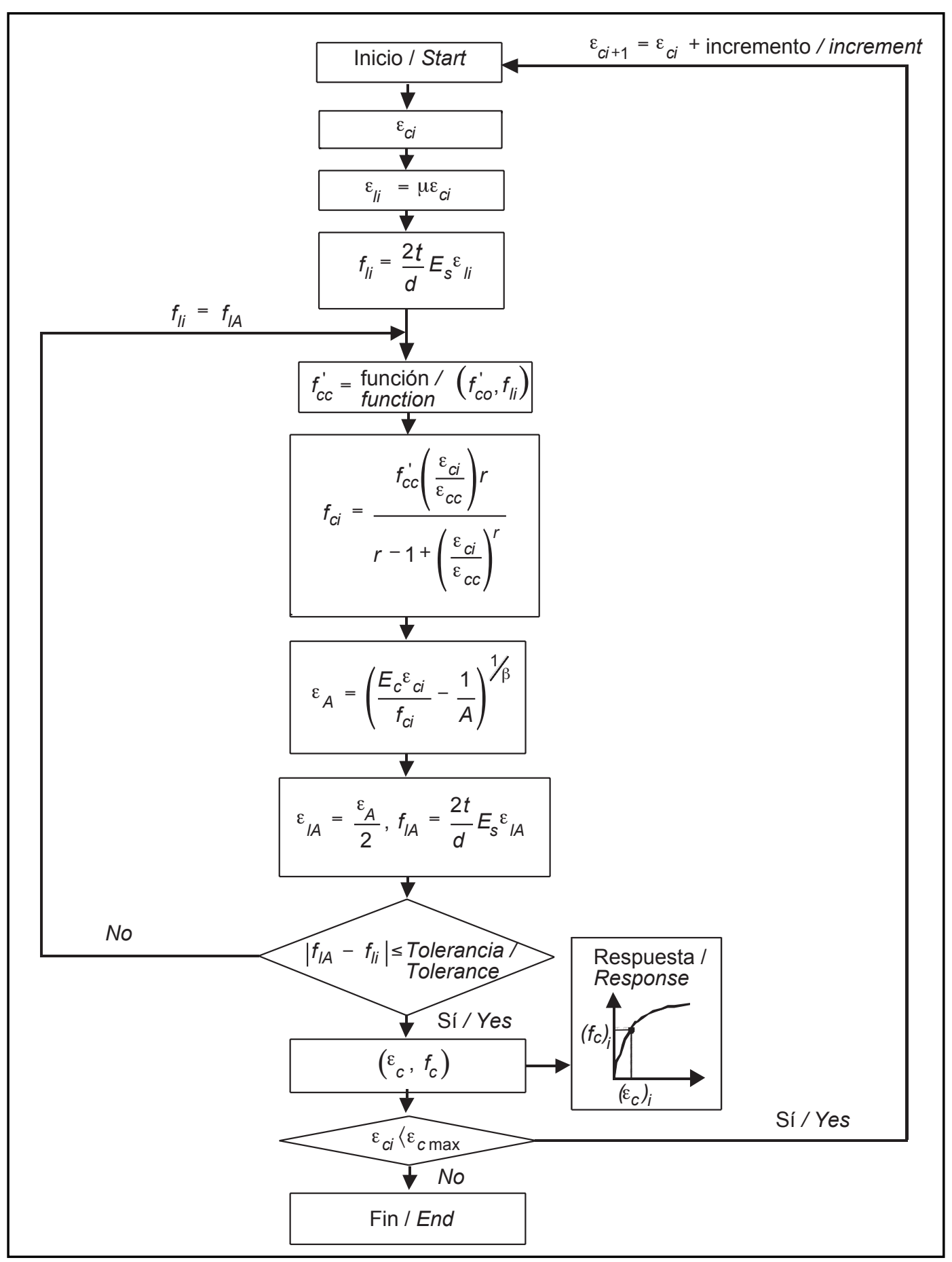

Figura 3. Diagrama de flujo del modelo de confinamiento. Figure 3. Flow chart for the confinement model.

Las Figuras 4 a 7 muestran la comparación de las respuestas tensión-deformación obtenidas experimentalmente y mediante el modelo propuesto. En todos los casos se empleó el criterio de rotura de Mander et al. (17). En general, se puede decir que el modelo utilizado es bastante representativo del comportamiento tensióndeformación de los hormigones estudiados. En la mayoría de los casos se alcanza aproximadamente el mismo
Figures 4 to 7 compare the experimental and analytical stress-strain responses. The Mander et al. (17) failure criterion was used throughout. The model was found to represent the stress-strain behaviour of the concretes studied fairly well. In most cases the maximum stress was approximately the same and the differences between the analytical and experimental values could be attributed to the fact that the model was originally 
nivel de tensión máxima y las diferencias entre los valores analíticos y experimentales podría atribuirse al hecho de que el modelo se basa originalmente en el caso donde el confinamiento lateral y longitudinal se materializa mediante estribos. developed for cases where specimens were wrapped in stirrups, laterally and longitudinally.
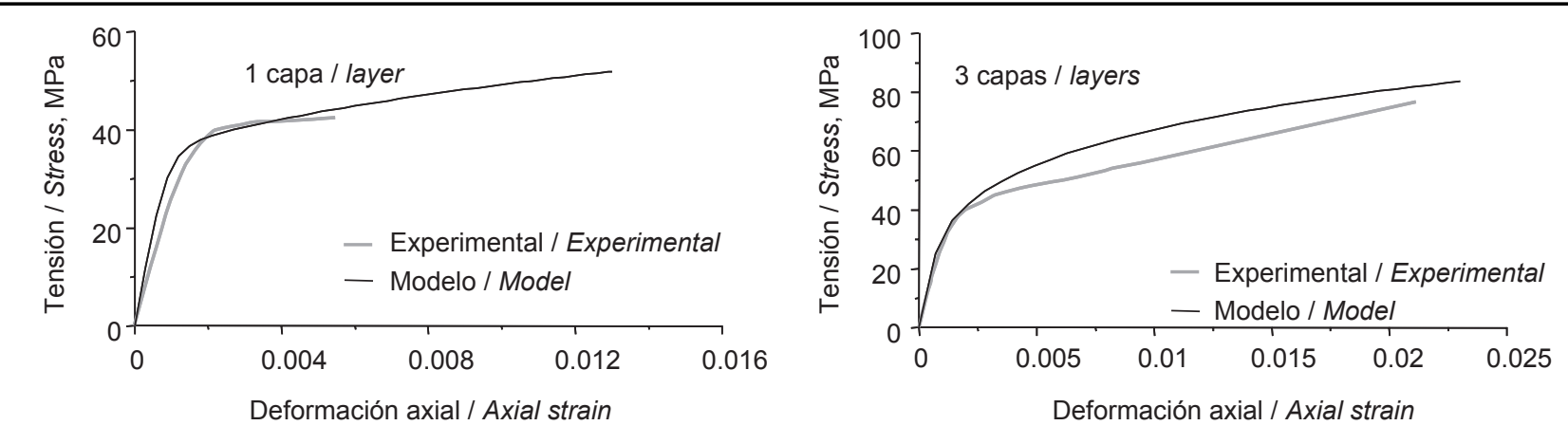

Figura 4. Comparación entre los resultados experimentales y el modelo propuesto para el hormigón HF30 con FRP de carbono. Figure 4. Experimental and proposed model stress-strain curves for carbon fibre-FRP confined HF30.

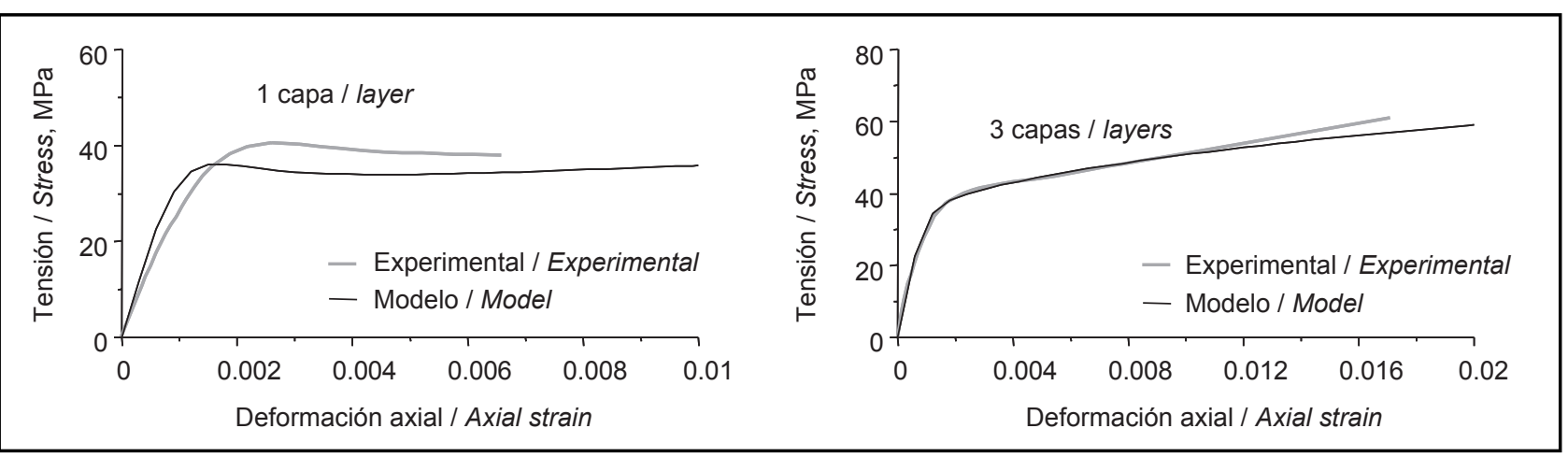

Figura 5. Comparación entre los resultados experimentales y el modelo propuesto para el hormigón HF30 con FRP de vidrio. Figure 5. Experimental and proposed model stress-strain curves for fibreglass-FRP confined HF30.

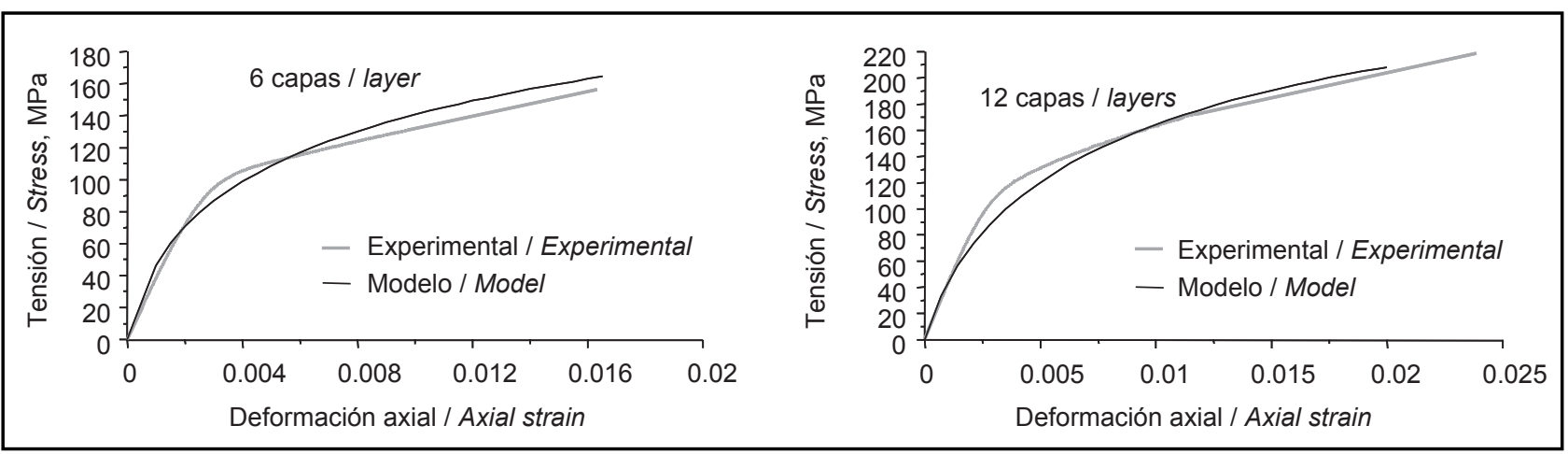

Figura 6. Comparación entre los resultados experimentales y el modelo propuesto para el hormigón HF70 con FRP de carbono. Figure 6. Experimental and proposed model stress-strain curves for carbon fibre-FRP confined HF70. 


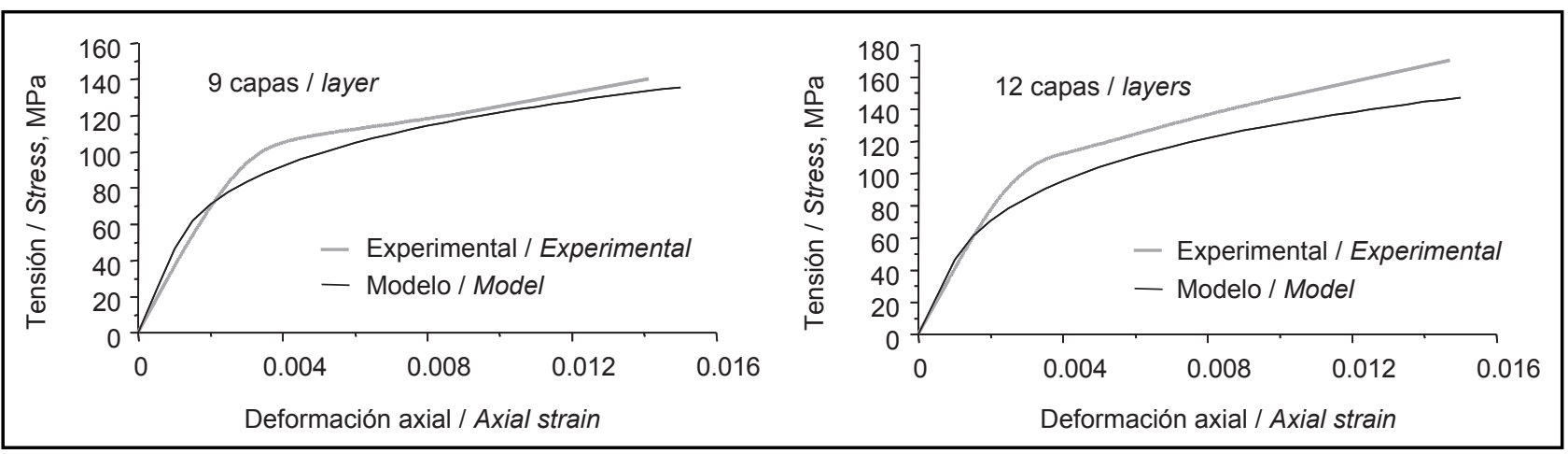

Figura 7. Comparación entre los resultados experimentales y el modelo propuesto para el hormigón HF70 con FRP de vidrio. Figure 7. Experimental and proposed model stress-strain curves for fibreglass-FRP confined HF70.

\section{CONCLUSIONES}

Se han ensayado a carga axial de compresión cilindros de hormigón de resistencia normal y alta confinados con un número variable (hasta 12) de capas de polímeros reforzados con fibra (FRP) de vidrio y carbono, y se determinaron sus propiedades mecánicas y respuesta tensión-deformación. Los resultados muestran que el confinamiento incrementa la resistencia y deformación del hormigón, siendo mayor el efecto en el hormigón de menor resistencia. El modo de rotura en los hormigones confinado con fibra de vidrio es gradual, mientras que las confinadas con fibra de carbono es repentina y explosiva. Para multicapas de confinamiento, la respuesta tensión-deformación presenta un comportamiento de endurecimiento en el post-pico. Las mayores resistencias se alcanzaron cuando los cilindros fueron confinados con fibras de carbono, lo que se debe principalmente a la mayor rigidez de este tipo de fibras. Se ha elaborado un modelo analítico que describe el comportamiento tensión-deformación del hormigón confinado con fibra, que resultó aplicable a los resultados experimentales, ya que en la mayoría de los casos se alcanza aproximadamente los mismos niveles de resistencia máxima y similar comportamiento tensión-deformación.

\section{CONCLUSIONS}

Normal and high-strength concrete cylinders with a variable number (up to 12) of layers of fibreglass- and carbon fibre-reinforced polymers (FRP) were tested under axial compression loads to determine their mechanical properties and stress-strain response. The findings showed that confinement raised concrete strength and ultimate strain and that this effect was greater in lower strength concrete. The failure mode in fibreglass-confined concrete was gradual, but sudden and explosive in the specimens confined with carbon fibre. In multi-layer confinement, the stress-strain response denoted post-peak hardening. The highest strength values were attained when the cylinders were confined with carbon fibres, due primarily to the greater stiffness of this type of fibre. The analytical model developed to describe the stress-strain behaviour in fibre-confined concrete was verified by the experimental results, as approximately the same strength levels and similar stress-strain behaviour were found in most cases.

\section{BIBLIOGRAFÍA / BIBLIOGRAPHY}

(1) Toutanji, H. y Deng, Y. (2001): "Performance of concrete columns strengthened with fiber reinforced polymer composite sheets". Advanced Composite Materials, vol. 10, no 23, pp. 159-168. doi:10.1163/156855101753396636

(2) Rousakis, T.; Karabinis, A. y Kiousis, P. (2007): "FRP-confined concrete members: Axial compression experiments and plasticity modeling". Engineering Structures, vol. 29, July 2007, pp. 1343-1353. doi:10.1016/j.engstruct.2006.08.006

(3) Mandal, S.; Hoskin, A. y Fam, A. (2005): "Influence of concrete strength on confinement effectiveness of fiber reinforced polymer circular jacket". ACI Structural Journal, vol. 102, no 3, May-June 2005, pp. 383-392.

(4) Teng, J. y Lam, L. (2004): "Behavior and modeling of fiber reinforced polymer-confined concrete". ASCE Journal of Structural Engineering, vol. 130, no 11, November 2004, pp. 1713-1723. doi:10.1061/(ASCE)0733-9445(2004)130:11(1713)

(5) Mirmiran, A. y Shahawy (1997): "Behavior of concrete columns confined by fiber composites". ASCE Journal of Structural Engineering, vol. 123, no 5, May 1997, pp 583-590. doi:10.1061/(ASCE)0733-9445(1997)123:5(583) 
(6) Harmon, T.; Slattery, K. y Ramakrishran, S. (1995): "The effect of confinement stiffness on confined concrete nonmetallic (FRP) reinforcement for concrete structures". Proceeding of the Second International RILEM Symposium (FRPRCS-2), pp. 584-592.

(7) Larralde, J. (1997): "Compressive strength of small concrete specimens confined with fiberglas laminates". Cement, Concrete and Aggregates, vol. 19, no 1, pp. 17-21. doi:10.1520/CCA10016]

(8) Toutanji, H. (1999): "Stress-strain characteristics of concrete columns externally confined with advanced fiber composite sheets". ACI Materials Journal, vol. 96, no 3, May-June, pp. 397-404.

(9) Xiao, Y. y Wu, H. (2000): "Compressive behavior of concrete confined by carbon fiber composite jackets", ASCE Journal of the Material in Civil Engineering, vol. 12, no 2, May, pp. 139-146. doi:10.1061/(ASCE)0899-1561(2000)12:2(139)

(10) Spoelstra, M. y Monti, G. (1999): "FRP confined concrete model", ASCE Journal of Composites for Construction, vol. 3, no 3 August 1999, pp. 143-150. doi:10.1061/(ASCE)1090-0268(1999)3:3(143)

(11) Razvi, S. y Saatcioglu, M. (1999): "Confinement model for high strength concrete", ASCE Journal of Structural Engineering, vol. 125, no 3 March 1999, pp. 281-289. doi:10.1061/(ASCE)0733-9445(1999)125:3(281)

(12) ACI-440 (2002): "Guidelines for the design and construction of externally bonded FRP systems for strengthening concrete structures". ACI 440, Detroit, USA.

(13) CSA (2002): "Design and construction of building components with fiber-reinforced polymers". CSA-S806-02, CSA Rexdale, Toronto, Canada.

(14) fib (2001): "Externally bonded FRP reinforcement for RC structures". Task Group 9.3 FRP, fib CEB-FIP July.

(15 JSCE (1997): "Recommendation for design and construction of concrete structures using continuous fiber reinforcing materials". Concrete Engineering Series 23, October, Tokyo, Japon.

(16) Marqués, C. S. y Marqués, C. D. (2000): "Modelagem do comportamento de concreto de alta resistencia sobre condicões de confinamento", Ibracon, 42 Congreso Brasileiro do Concreto, II-A-018.

(17 Mander, J.; Priestley, M. y Park, R. (1988): "Observed stress-strain behavior of confined concrete". Journal of Structural Engineering, vol. 14, no 8, pp. 1827-1849.

(18) Cusson, D. y Paultre, P. (1995): "Stress-strain model for confined high strength concrete", ASCE Journal of Structural Engineering, vol. 121, no 3, pp. 468-477. doi:10.1061/(ASCE)0733-9445(1995)121:3(468)

(19) Pantazopoulou, S. y Mills, R. (1995): "Microstructural aspects of the mechanicals response of plain concrete". ACI Materials Journal, vol. 92, nº 6, Nov.-Dec., pp. 605-616. 